\title{
29. REGIONAL PROBLEMS
}

\author{
Edward L. Winterer, Scripps Institution of Oceanography, La Jolla, California
}

\section{INTRODUCTION}

Problems of regional scope are treated in this chapter. No attempt is made to be exhaustive: Each reader will synthesize the cruise data according to his own lights, and each reader will weave his own interpretations from these syntheses. The major topics treated here-some in more, some in less detail-are: (1) crustal age patterns, (2) seamount chains, (3) plateaus, and (4) regional sedimentary history, which is further subdivided into sections on post-Eocene, early Cenozoic, and Cretaceous strata.

For convenient reference, the summary graphic logs from each site are reproduced here (Figure 1), as well as a regional bathymetric chart (Figure 2), on which the drill sites are shown.

\section{CRUSTAL AGE PATTERNS}

Prior to Leg 17, the following features of crustal age patterns in the central Pacific were known: (1) A set of parallel magnetic anomalies (the Phoenix anomalies) had been discovered near the equator by Larson et al. (1972), and it was thought that these anomalies correlated with a northwest-trending set near the Hawaiian Seamount Chain and with a southwest-trending set north of Shatsky Rise (Larson and Chase, 1972). No ages or age gradients could be assigned to these anomaly sets, although extrapolations from dated anomalies 1-32 westward to the Hawaiian set yielded a range of Late Triassic to Early Cretaceous (Hayes and Pitman, 1970). (2) Drilling at Site 66 on Leg 7 (Winterer et al., 1971a) gave a probable age of Turonian or Cenomanian for basal clayey sediments resting on basalt, but it was not certain that the basalt was typical rise-crest tholeiite. The lack of any calcium carbonate in the lower sediments at Site 66 is odd, if the site was once in water as shallow as typical rise crests $(\sim 2700 \mathrm{~m})$. Site 66 thus gives only a minimum age for oceanic crust. (3) Dredging of seamounts in the Mid-Pacific Mountains (Hamilton, 1956; Lonsdale et al., 1972) had recovered Albian and Aptian fossils, and a dredge from a seamount in the Line Islands yielded Senonian planktonic fossils. (4) Drilling at Site 65 (Winterer et al., 1971b) recovered reworked Maastrichtian planktonic foraminifera in an Eocene turbidite.

The results of drilling at Site 166 now give an age of approximately $120 \mathrm{~m} . \mathrm{y}$. for a point between anomalies M-7 and $\mathrm{M}-8$ on the Phoenix anomalies, and the results at Site 167 further suggest that ages increase northward on this set. An average spreading rate of from 2 to $4 \mathrm{~cm} / \mathrm{yr}$ is deduced for the crust between these two sites. The parallelism of linear bathymetric features around Site 167 to the magnetic and bathymetric trends around Site 166 suggest they belong to the same spreading-ridge system.

The other piece of crustal age data from Leg 17 is that the age of the crust at Site 164 is probably about 100 to
115 m.y. Since no magnetic anomaly pattern can be detected, and since bathymetric trends are ill-defined in the vicinity of the site, attempts to fit this bit of crust into a regional pattern are speculative. The date is useful, though, in helping to put limits on the age of the beginning of the "magnetic quiet zone," which probably corresponds to the period between anomaly M-1 of the Phoenix set and anomaly 32 .

The distance between Site 164 and anomaly 32 (75 m.y.) south of the Molokai Fracture Zone is about 1,800 $\mathrm{km}$, and the age difference lies between 25 and $40 \mathrm{~m} . \mathrm{y}$., giving average spreading rates, on a straight line, of from 4.5 to $7.2 \mathrm{~cm} / \mathrm{yr}$. This result may be grossly incorrect because of: (1) a possible fracture zone between the Molokai and Clarion, separating Site 164 from the place where anomaly 32 is recognized; (2) undetected abandoned rise crests ("jumped" ridges) east of Site 164; and (3) marked changes in spreading directions between anomaly 32 and Site 164 .

No strong evidence can be seen for any additional fracture zones near Site 164, but linear features parallel to the Molokai, shown on a bathymetric chart of the North Pacific (Chase et al., 1971) near $140^{\circ} \mathrm{W}$, suggest one may be present at anomaly 32 . No obvious jumped ridges, with eastward-aging crust, can be seen in the bathymetry, but any such abandoned rise crests would be very hard to find in old crust because of the flatness of the age versus depth curves beyond about 75 m.y. (Sclater et al., 1971), but the possibility cannot be ruled out. As for changes in spreading directions, the Clarion Fracture Zone does appear to bend more southwesterly at about $152^{\circ} \mathrm{W}$, but the amount of bending is too small to seriously affect estimates of average rates of spreading based on a straight-line assumption.

The most serious difficulties in constructing a crustal age map come from the effects of younger vulcanism. The Mid-Pacific Mountains and the Line Islands Seamount Chain, like other seamount chains, are probably somewhat younger than the crust on which they rest, and they may have obliterated magnetic lineation patterns in the crust they cross. If younger vulcanism were confined strictly to seamounts and their immediate environs, we could deal more confidently with the deep-sea floor away from the seamounts; that is, we could use the drill to determine the "true" age of the oceanic crust, and could regard the absence of magnetic lineations as having possible age significance-a "quiet zone." But the possibility that younger vulcanism may not be manifested everywhere by seamounts or ridges can make crustal age interpretations from drill results very uncertain. From results at Site 165, it is clear that alkali basalts like those commonly found on seamounts can be extruded on the deep-sea floor some tens of kilometers from any large seamount. With this danger in mind, we can now try to interpret the data that bear on the age of the region between Magellan Rise and the Mid-Pacific Mountains. 


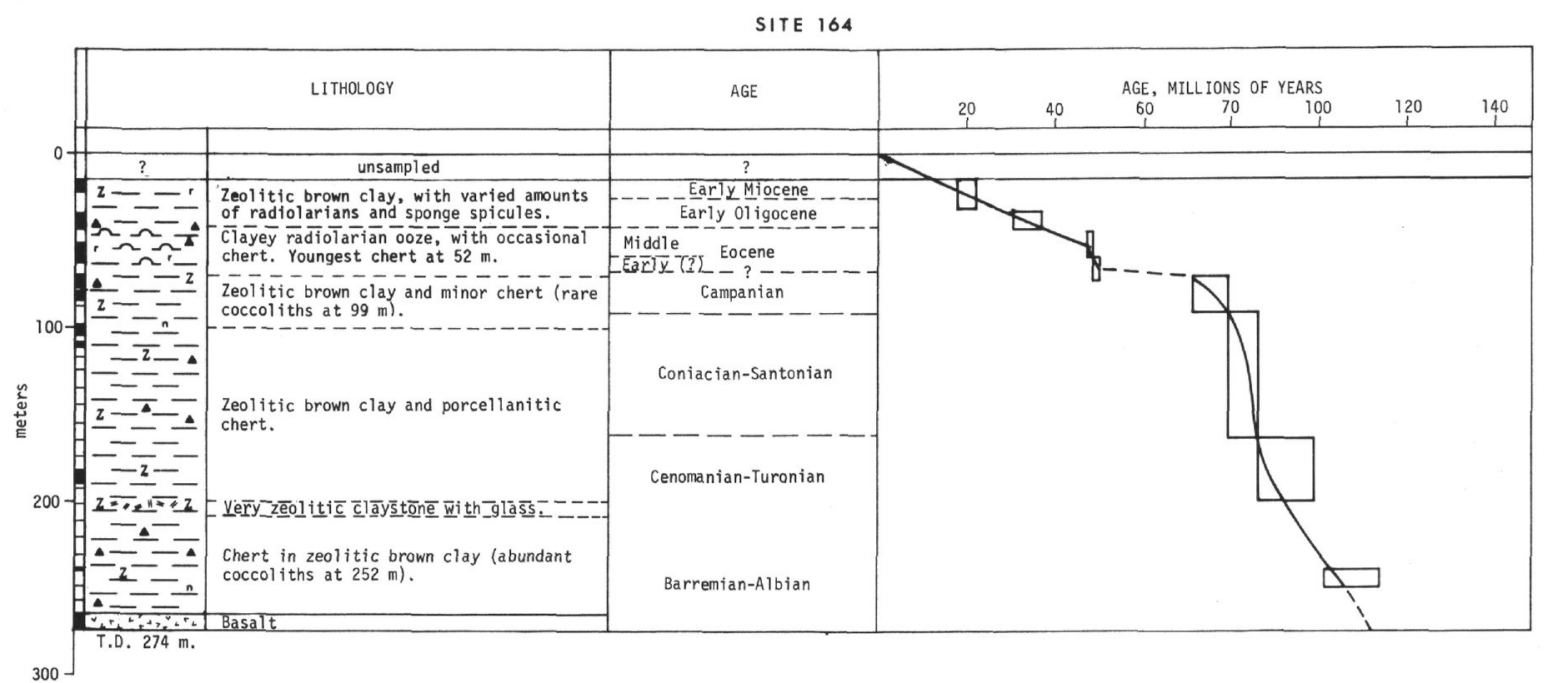

Figure 1. Graphic logs and rate of accumulation diagrams for each site drilled on Leg 17.

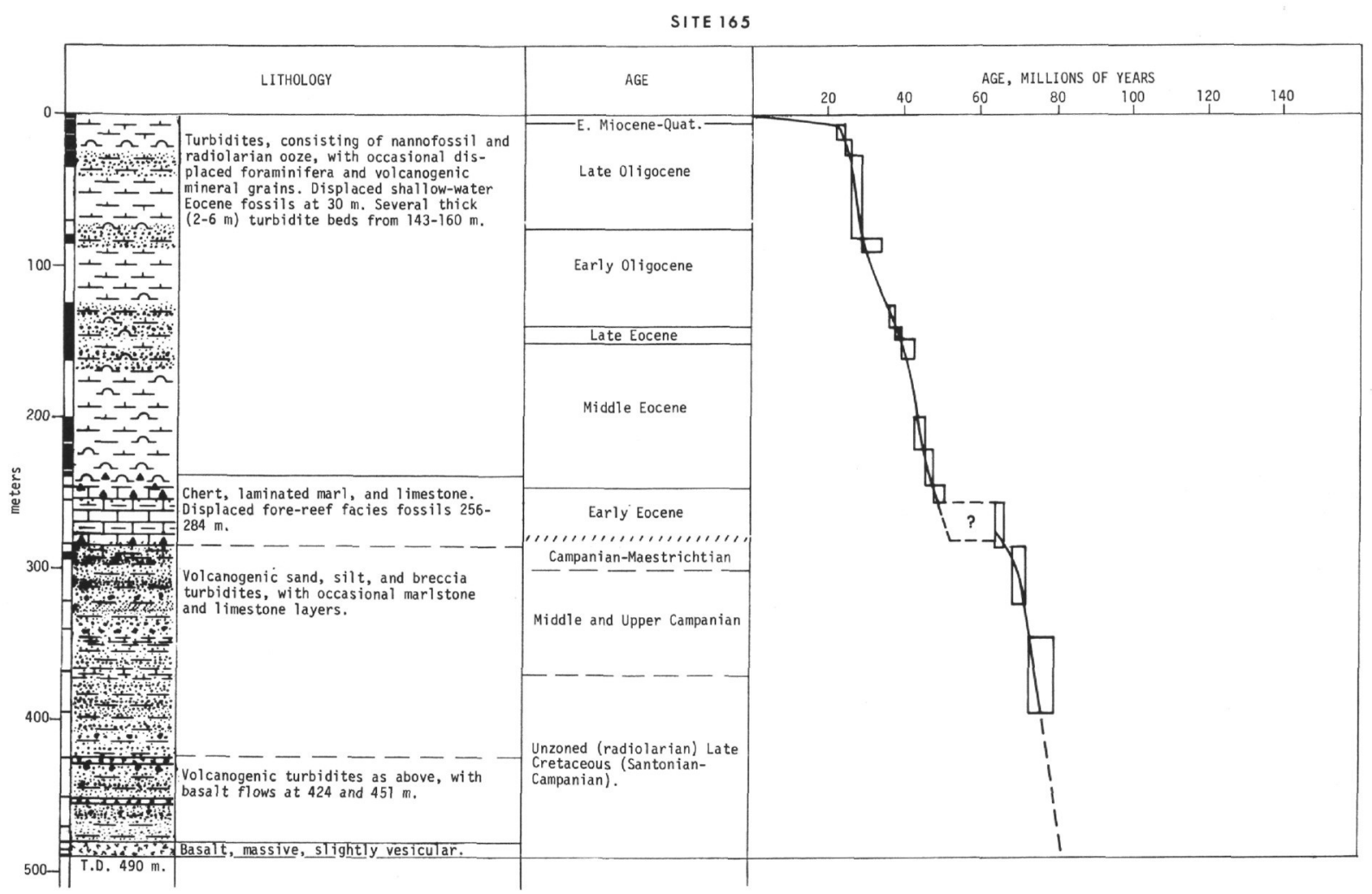

Figure 1. (Continued). 


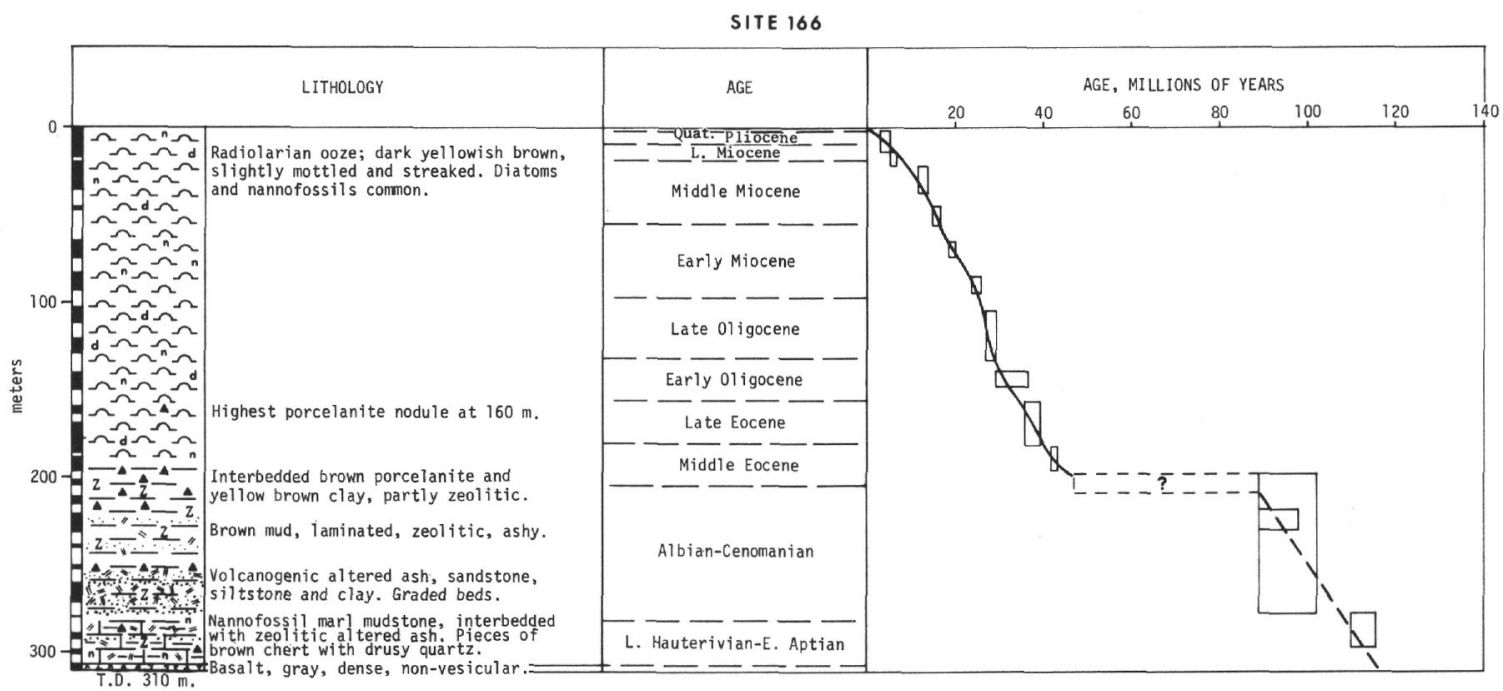

Figure 1. (Continued).

The bathymetric chart of the Central Basin (Figure 2) shows prominent northwest-trends in a band extending from the Line Islands Ridge to the Marshall Islands. Water as deep as 6000 meters is common along the southern part of this band, close to Magellan Rise. Reflection profiler records near Site 170 in this region (see chapter on Underway Geophysical Data) look little different from records near Site 166 with respect to relief of the acoustic basement. From the point of view of average depth, the region around Site 170 looks less suspicious as "normal" sea floor than at Site 166, which is on a broad swell about 500 meters shallower than its surroundings. Thus, there is no compelling reason to believe that the crust in the band north of Magellan Rise is anything other than normal oceanic crust, generated at a rise crest. The lineated topography does not extend to Site 169 , which is on a long smooth basement slope, extending away from the Marshall Islands Ridge. Site 66 might also lie along the band of lineated topography, but sounding lines are too few in the vicinity of Site 66 to establish any definite trends.

Drilling results at three separate sites located on or close to the band of northwest-trending topography (Sites 66, 169, and 170) give Middle Cretaceous ages for oldest sediments lying depositionally on basalt. Sites 169 and 170 both yield Albian (100 to 104 m.y.), and Site 66 yields Cenomanian to Turonian ( 87 to 100 m.y.) ages. These ages are within the magnetic "quiet zone" and are therefore consistent with the lack of any well-documented magnetic lineations along the band. We must therefore admit that unless it can be shown that the basalts at the bottom of the hole at Sites 66, 169, and 170 are younger than "true" oceanic basement, then there is a case for the presence of a band of Middle Cretaceous crust in the region north of Magellan Rise. At Site 169, the deepest basalts are tholeiitic pillow basalts, like those on oceanic ridges. The lineation of the topography suggests that crustal isochrons trend northwest. This interpretation implies a juxtaposition of ages along the north side of Magellan Rise, from about 135 m.y. to about 105 m.y. Because older, pre-Albian, crust also lies to the north, both in the region of the southwest-aging Hawaiian lineations and in the Mid-Pacific Mountains, the hypothesis implies a northwest-trending spreading ridge that originated about 105 million years ago, but ceased spreading after creating a band of crust no more than about $800 \mathrm{~km}$ wide-the distance from Magellan Rise to the older Mid-Pacific Mountains. At a spreading rate of only $2 \mathrm{~cm} / \mathrm{yr}$, this band would have taken only 20 m.y. to form, and at faster rates it would have an even shorter life. The length of the band of northwest-trending lineations is unknown, but it appears to extend clear across the Central Basin (a distance of about $3000 \mathrm{~km}$ ) and may continue westward along the Marcus Ridge.

The case against a Middle Cretaceous spreading center north of Magellan Rise rests chiefly on the results at Site 170 , the only site definitely on the bathymetric trend. The basalt at Site 170, from textural evidence and lack of glass or pillow structure, is interpreted as a sill by Bass (see chapter on Igneous Rocks), and is so altered that unequivocal assignment to a class of basalts is impossible, though ocean-island or alkali basalt affinities are favored over ocean-ridge tholeiite. More sediment may thus lie unsampled beneath the basalt. The reflection profiler record at the site shows only about $0.2 \mathrm{sec}$ of sediment above acoustic basement, but about $100 \mathrm{~km}$ southwest of the site, the record (see chapter on Underway Geophysical Records, at 1600-1700 hr, May 11, 1971), shows nearly twice that thickness of section, with a thin prominent intermediate reflector at about the same depth below the sea floor as the acoustic basement at Site 170. Keeping in mind the variations in sediment thickness shown over short distances on the profiler record, especially between topographic highs and lows, it would still appear plausible that a considerable section of sediments, perhaps as much as 150 meters, might lie beneath the basalt at Site 170 . Finally, at both Sites 169 and 170 sills or flows of basalt were drilled through, well above acoustic basement, showing that younger volcanic events have actually occurred within the area of interest.

If the acoustic basement at Site 170 is a sill or young flow, then we can only say that the "true" oceanic crust is 
SITE 167

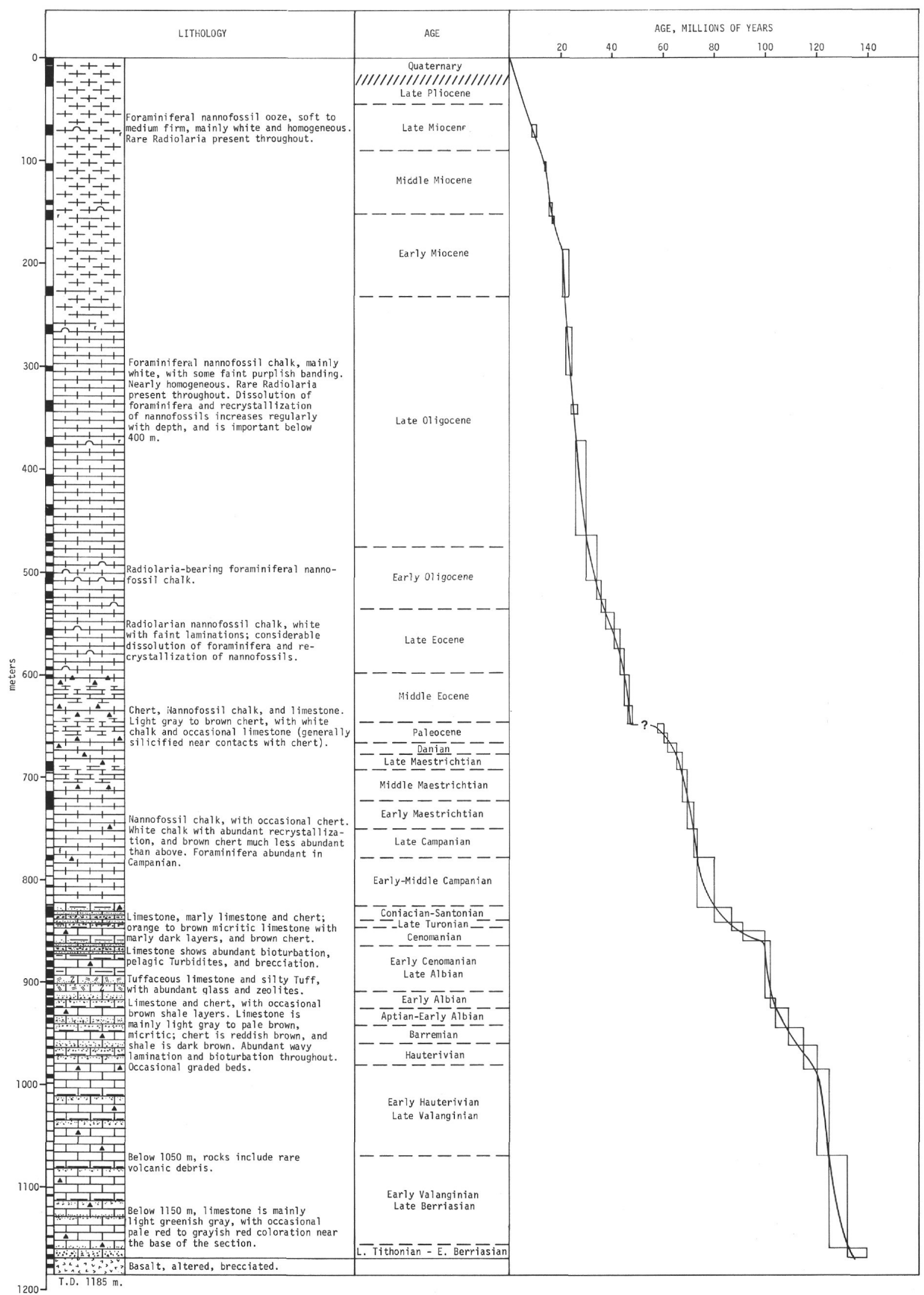

Figure 1. (Continued). 
SITE 168

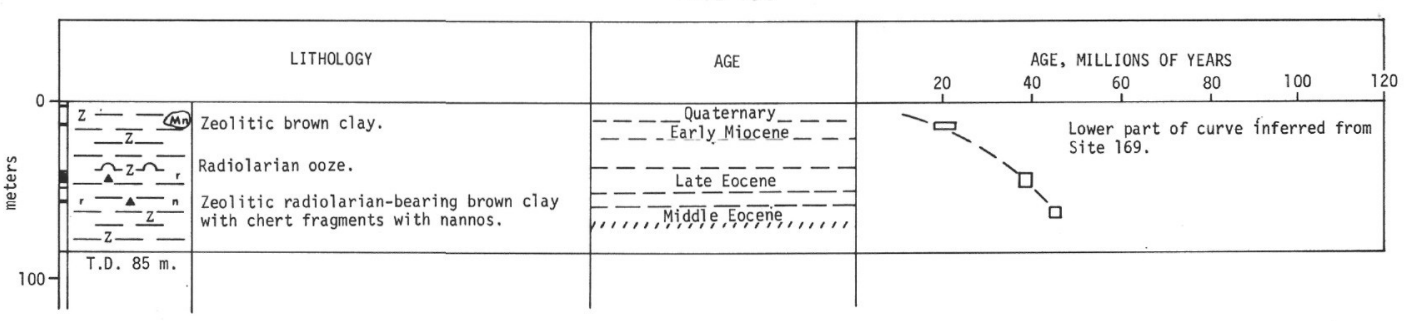

Figure 1. (Continued).

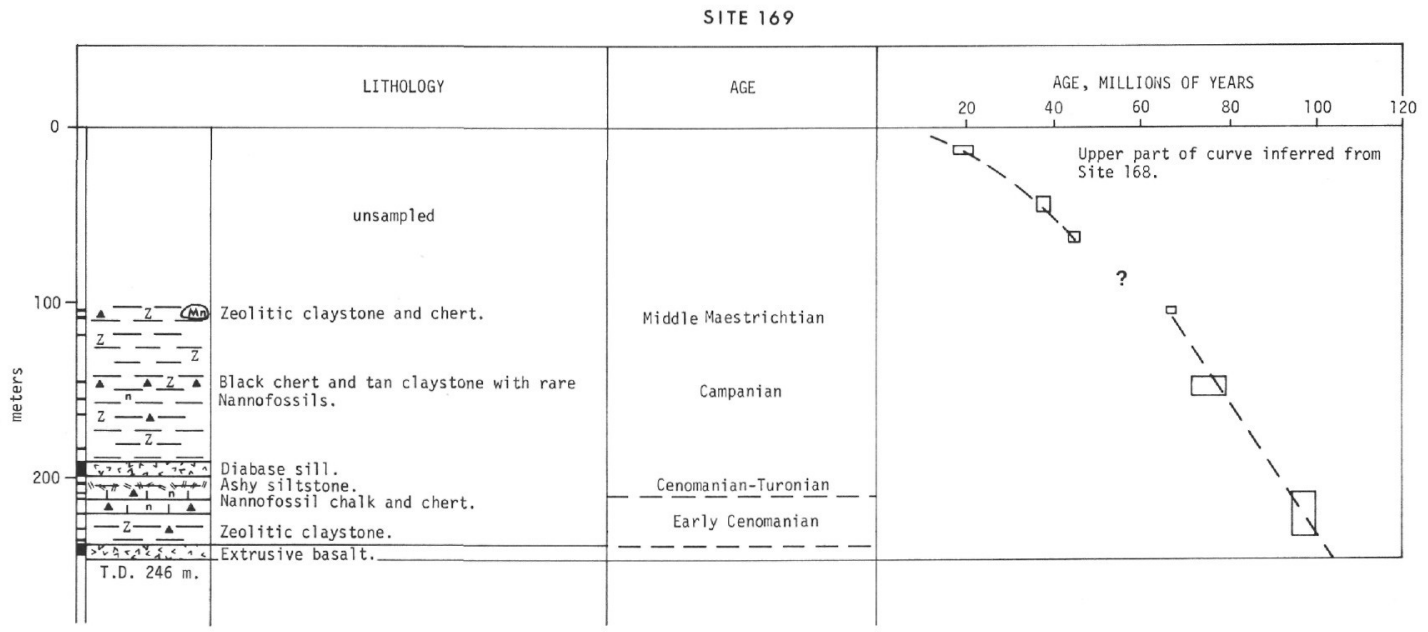

Figure 1. (Continued).

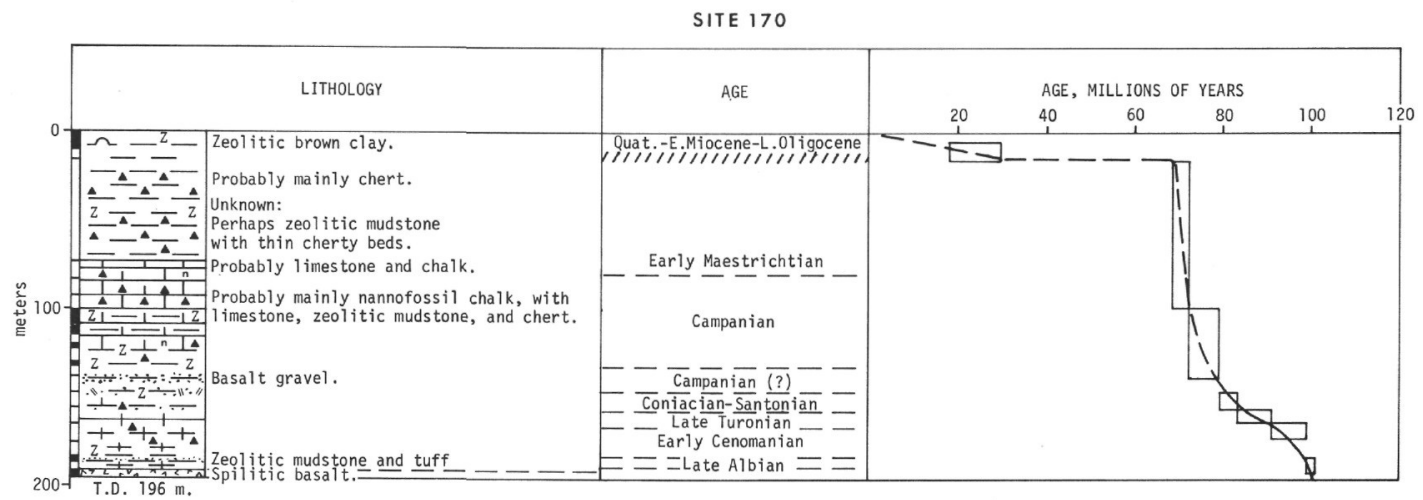

Figure 1. (Continued).

older than 105 m.y. If the rock is not an ocean-ridge tholeiite, then the crustal age may be considerably older. The most conservative hypothesis is that the crust is close to the age of the crust at Magellan Rise, which is probably about 135 m.y. Two simple models can be contrasted: (1) Magellan Rise is along a line of triple junctions, forming an acute-angle "bight" between the Phoenix and Site 170 lineations. The age gradient at Site 170 in this case is younger toward the north, and a simple scheme of transform faults would connect this pattern with the Hawaiian lineations. (2) Magellan Rise is at a place where a spreading ridge realigned itself, or rather, the spreading direction changed from northeast to southwest along the older Site 170 Ridge to a new northwest-southeast direction along the Phoenix Ridge in the same way that the
Pacific-Farallon Ridge was replaced by the Juan de Fuca Ridge in the northeast Pacific. The age gradient at Site 170 in this case is older toward the north, and some kind of triple junction is then required between the Site 170 Ridge system and the Hawaiian lineations. Until more data on lineations and crustal ages are available, there is no firm basis on which to choose between these last two models. Either seems more plausible than a short-lived, cross-cutting spreading ridge required by acceptance of an Albian age for oceanic basement at Site 170.

\section{LINEAR SEAMOUNT CHAINS}

The drilling at Site 165 showed the feasibility of drilling on archipelagic aprons to obtain the date of cessation of vulcanism and the subsidence (and uplift) history of a 


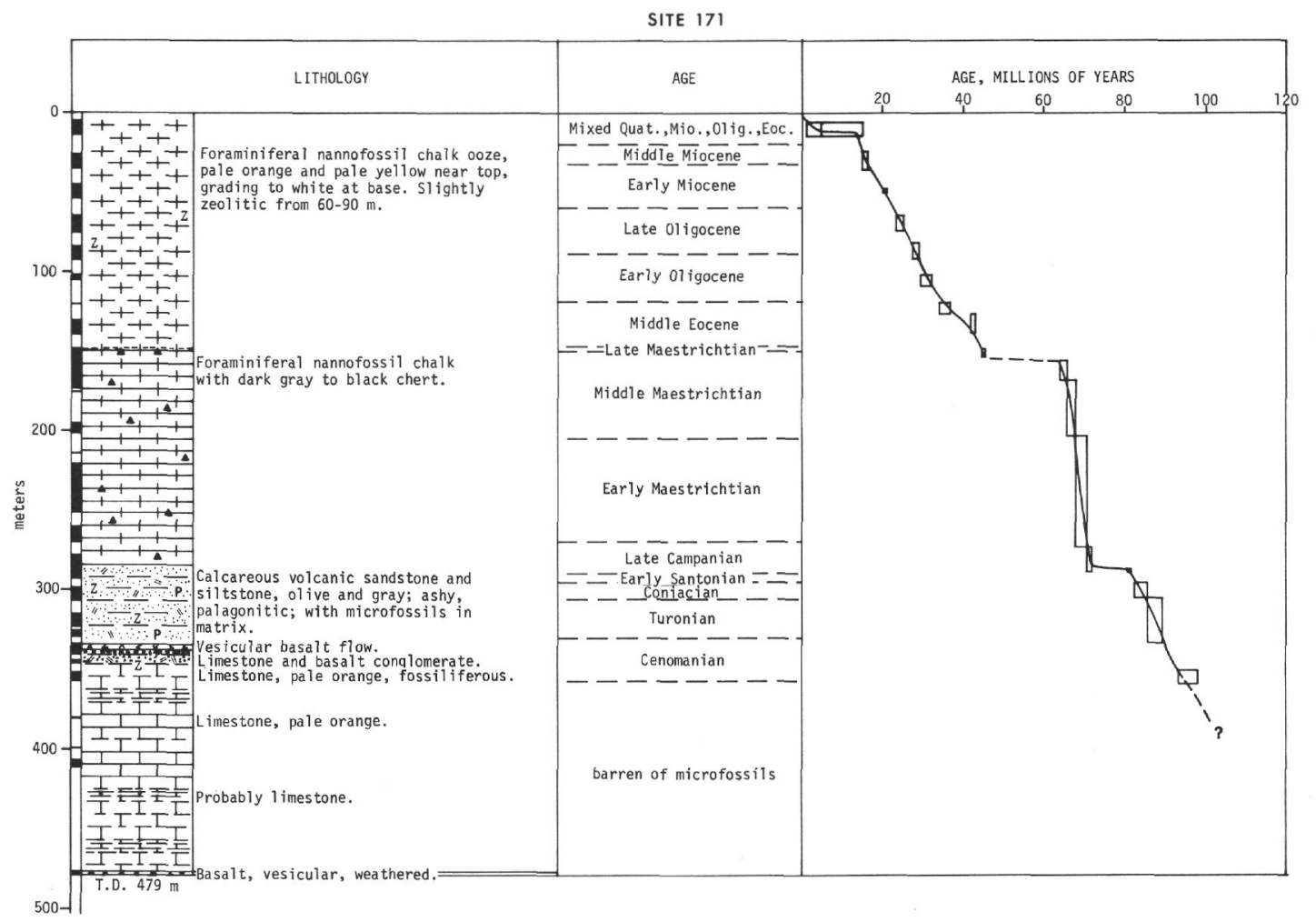

Figure 1. (Continued).

segment of a seamount chain. The vulcanism that is dated is on alkalic flows emplaced in deep water near the seamounts. The existence of the seamounts as topographic highs is evidenced by the turbidites that overlie the flows. It is clearly possible that (1) volcanism on the seamounts ceased long before it did on adjacent deep-sea floor, or (2) volcanism continued on the seamounts long after it had ceased on the deep-sea floor, but left no record in the sediments. It is not possible to reject the first possibility, but the second seems unlikely. The "date" obtained is thus a minimum age for the seamounts.

During Leg 17, holes were drilled on or near three seamount chains: the Line Islands (Site 165), the Marshall Islands (Site 169), and the Mid-Pacific Mountains (Site 171). On none of the three chains have enough other dates, along different parts of the chains, been determined to make possible a test of any of the current theories of the formation of seamount chains. The date at Site 165 is from a part of the Line Islands Chain near a prominent "crosstrend," comprising a northwest-trending lines of seamounts. The site lies about $100 \mathrm{~km}$ south of this crosstrend and should therefore record events on the main trend; nonetheless, caution should be used in interpreting Site 165. Likewise, the data at Site 169 should be connected with the Marshall Islands Chain with even more caution. There are two volcanic events recorded at Site 169 , one at about $105 \mathrm{~m} . \mathrm{y}$. (the acoustic basement) and another during the Late Cretaceous (the sill above TuronianCenomanian sediments, with an authigenic K-feldspar K/A date of $58 \pm 2 \mathrm{~m} . \mathrm{y}$.). The site is nearly $300 \mathrm{~km}$ from the nearest seamounts in the Marshall Islands Chain. While there is little doubt as to the connection between Site 171 and Horizon Guyot, the dating of the oldest sediments is uncertain. The cessation of vulcanism about 90 million years ago, near the Cenomanian-Turonian boundary, appears well-established here. Since Albian (100 to 104 m.y.) planktonic foraminifera have been dredged on Horizon Guyot (Lonsdale et al., 1972), the volcanic activity spanned at least $10 \mathrm{~m} . \mathrm{y}$.

\section{PLATEAUS}

Drilling at Site 167 on Magellan Rise showed that the plateau has been continuously below sea level since the beginning of sedimentation, but has never been below the compensation depth for calcium carbonate long enough to allow deposition of a substantial record of carbonate-free clay.

Studies of the basement rocks by Bass et al. (see chapter on Igneous Rocks) suggest that the basement rocks may have ocean-island-tholeiite affinities and that the plateau may thus be akin to seamounts and may even be younger than the oceanic crust on which it rests. Bathymetric and crustal age data, on the other hand, suggest the plateau is a part of the Phoenix lineation pattern and may lie either next to an acute-angle ridge-ridge-ridge triple junction or to a place where there was a substantial $\left(40^{\circ}\right)$ change in spreading directions. Both Shatsky and Manihiki Plateaus appear to occupy similar positions with respect to patterns of crustal ages, suggesting that the special conditions required for forming a plateau are related to these patterns. For example, the very slow spreading within transform fault zones associated with changes in spreading direction (Menard and Atwater, 1968) could give rise to a considerable area of shallow depths. Alternatively, stabilization of a melting spot or convective plume at a RRR triple point might augment the normal rate of vulcanism along 


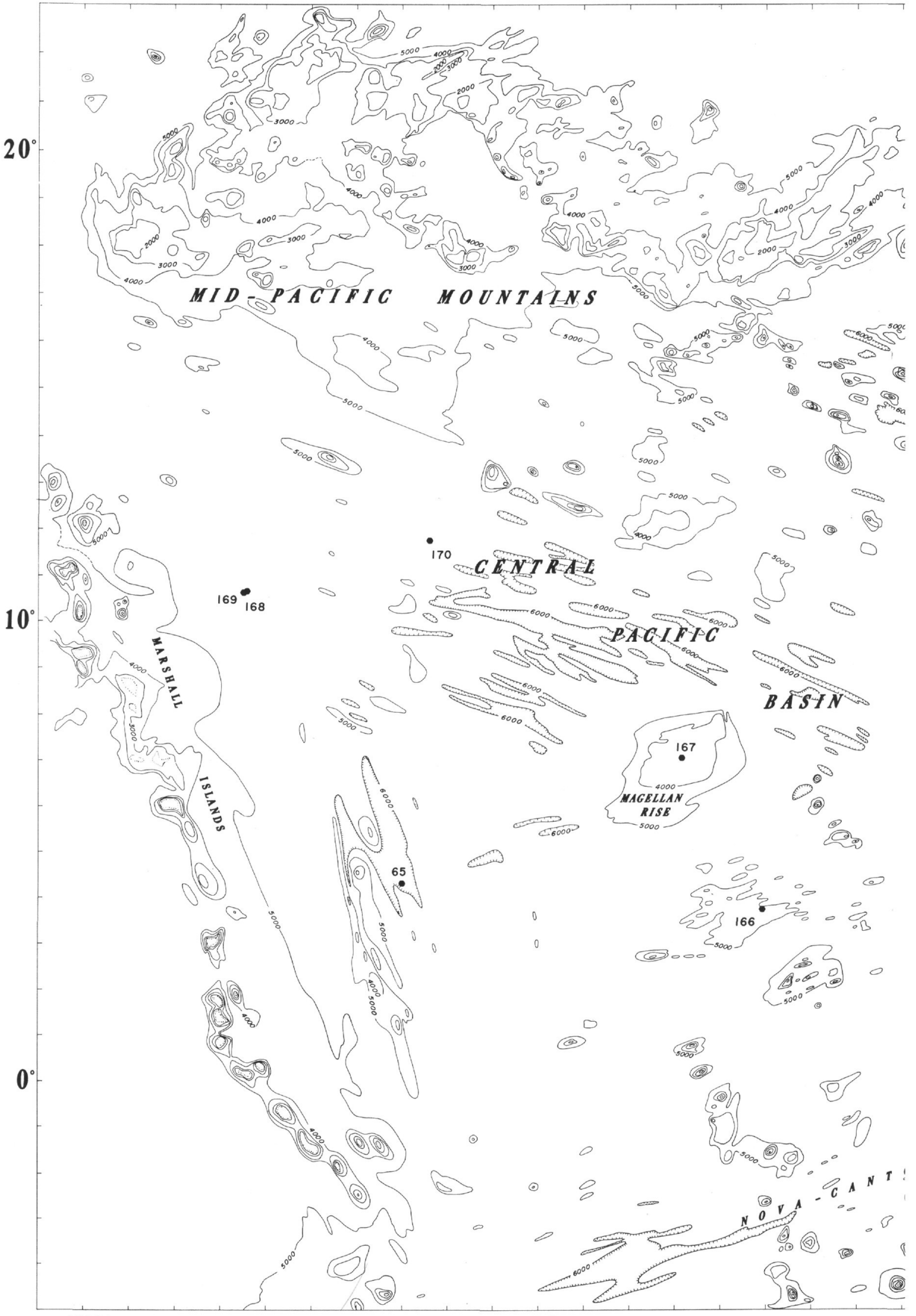

$170^{\circ}$

$180^{\circ}$

Figure 2. Generalized bathymetric chart of the Central Basin of the Pacific, showing JOIDES drill sites. Contour interval, 1 $\mathrm{km}$. Date from Chase et al. (1971), J. Mammerickx et al (unpublished), P. Lonsdale (unpublished), supplemented in the central part of the chart by contouring of new data furnished by Lamont-Doherty Geological Observatory, Hawaii Institute of Geophysics, and Scripps Institution of Oceanography. 


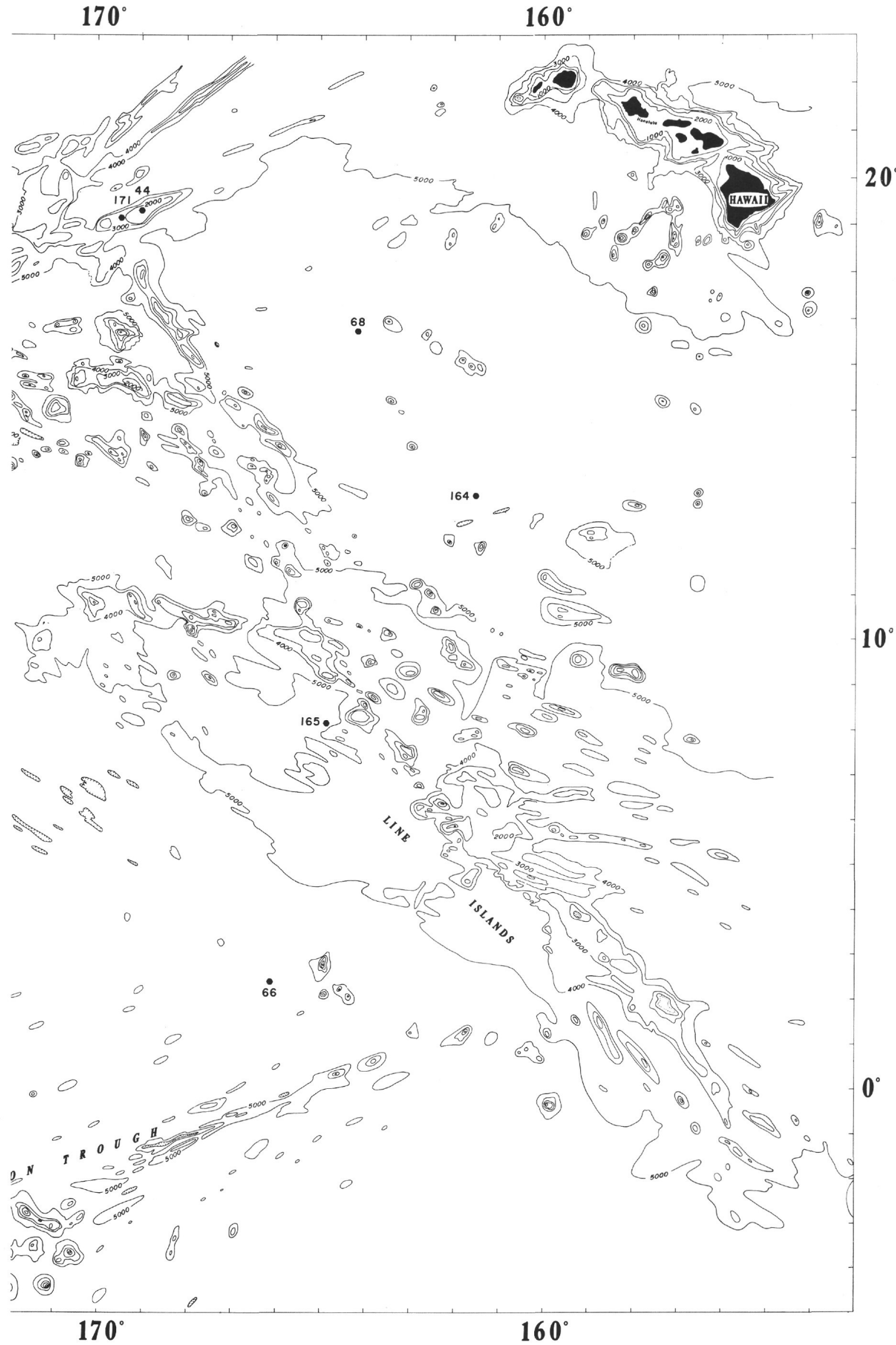

Figure 2. (Continued). 
the rise crests close to the junction. Affinities with ocean-island tholeiites might be anticipated in such a case. Although further studies of plateaus through drilling are required for sedimentological and stratigraphic purposes, it is equally necessary to study midocean plateaus more closely with conventional methods to learn in detail their patterns of basement relief and magnetic lineations.

\section{REGIONAL SEDIMENTARY HISTORY}

\section{Post-Eocene}

The main features of post-Eocene sedimentation in the Central Basin region are as follows:

1) Biogenous sediments accumulated near the equator accord in general with the latitude-depth-rate models of Berger (1973) and Winterer (1973). A northward component of plate motion, with respect to the equator, of about $2.5 \mathrm{~cm} / \mathrm{yr}$ will accommodate the observed patterns of sediment distribution and rates of accumulation. The most sensitive site for this model is Site 167, on Magellan Plateau at $7^{\circ} \mathrm{N}$, where Late Oligocene rates of accumulation were notably faster than at earlier or later times, suggesting an equatorial crossing about $25 \mathrm{~m} . \mathrm{y}$. ago. The post-Eocene paleodepths of most sites are either well above (Sites 167 and 171) or well below (Sites 164, 165, 168, 170) the most likely position of the calcium carbonate compensation depth (CCD) and give no new information of changes in depth of CCD during this time interval. A significant (greater than $300 \mathrm{~m}$ ) depression of the CCD during this time should have reflected itself in deposition of carbonate sediments at Site 166, which now lies just a little shallower than the CCD at 4962 meters. Nannofossils are sparingly present in all post-Eocene samples at this site, but only in one core, in the lower part of the Middle Miocene (15 m.y.), are there well-preserved planktonic foraminifera. This may record the passage of the site beneath the equator, where the CCD is depressed below regional averages, or a slight secular depression in the CCD. The rate of northward plate motion required is a little less than 3 $\mathrm{cm} / \mathrm{yr}$, which is consistent with the average rate for post-Ologicene times, derived from Site 167. Thus, the evidence from Site 166 suggests that the CCD in the equatorial region has had a stable configuration since Eocene times.

2) At most sites there are indications of very slow or even negative rates of accumulation in post-Middle Miocene times. Only Site 167, on Magellan Plateau may be unaffected. At Sites 165, 168, 170, and 171 the drill entered either directly into older sediments at the sea floor or penetrated only a few meters of post-Middle Miocene sediments. Reflection profiler records near Sites 165 and 168 show evidences of erosion of older sediments, and near Site 165 the $3.5 \mathrm{kH}$ records also show post-Early Miocene sediments in channels and as acoustically nearly transparent lenses on slopes near the foot of a seamount (see Site Report for records). The profiler record near Site 168 (see chapter on Underway Geophysical Records) also shows an area of deposition of young ponded sediments at the foot of a long slope that is patchily covered by the partly eroded sediments (1500-2300 hr, May 5, 1971).
A slowing of accumulation rates is expected for sites moving northward away from the equatorial zone of biogenous sedimentation. At $2 \mathrm{~m} / \mathrm{m}$.y. (a typical brownclay rate of accumulation) only 20 meters would be expected in 10 million years. The deep-water sites showing very low rates are now north of $8^{\circ} \mathrm{N}$, and no doubt this effect, combined with our difficulties in obtaining samples of near-surface sediments (see Operations sections of Site Reports), can explain the skimpy sections. On the other hand, the results at Site 171, on Horizon Guyot, and the profiler evidence of erosion at Sites 165 and 168 suggest that there has been an increase in erosion and sediment transport by bottom currents sometime in the past $10 \mathrm{~m} . \mathrm{y}$., as compared to earlier times. These effects were felt in deep water along the lower slopes of the Marshall Island Arch, near deep passes through the Line Islands Seamount Chain, and in shallower water, on Horizon Guyot. One might expect increased deep-water circulation as a consequence of late Cenozoic glaciation and the formation of large quantities of cold bottom waters in the circum-Antartic region, but the extent to which such events are felt in distant regions depends on a host of local conditions; e.g., the location and depth of sills over which bottom waters pass in reaching the local area. These "valves" can be affected in turn by such events as the construction of new volcanoes or trenches and by plate motion.

\section{Early Cenozoic}

In the central Pacific, the early Cenozoic record has several puzzling features that make it quite unlike the later Cenozoic or the Cretaceous. The anomalies are: (1) The very widespread occurrence of chert in the Eocene, especially in the Middle Eocene; (2) The prevalence of an unconformity between Eocene beds (commonly near the Middle/Lower Eocene boundary) and older Cenozoic or Cretaceous beds below; and (3) The dearth of Lower Eocene, Paleocene, and Danian sediments.

Chert occurs in Middle Eocene beds at seven of the eight sites drilled on Leg 17 . At Site 170, core recovery was very poor in Cenozoic sediments, but the drilling record shows many hard (cherty?) layers in pre-late Oligocene post-early Maastrichtian beds, in an unsampled interval about 55 meters thick. Middle Eocene cherts occur as nodules and thin beds in limestone (Sites 165, 167, 171), in radiolarian ooze (Sites 164, 166), and probably in brown clay (Sites $168,169,170)$.

The youngest occurrences of chert have a large stratigraphic range. At two sites, chert occurs in beds younger than Middle Eocene. At Site 164, chert occurs in Lower Oligocene ( 34 to $38 \mathrm{~m}$.y.) radiolarian-rich zeolitic clay, and at Site 168, the youngest chert is in Upper Eocene (38 to 43 m.y.) radiolarian-bearing zeolitic clay. At other sites, the highest Middle Eocene chert is not everywhere at the same stratigraphic level. At Site 166, the chert is first encountered in the Podocyrtis goetheana radiolarian zone (43 to 44 m.y.); at Site 167 , in the $P$. chalara Zone ( 44 to 45 m.y.); at Site 171, in the P.13 foraminiferal zone (44 to 46 m.y.); and at Site 165, in the Thyrsocyrtis triacantha radiolarian zone ( 47 to $48 \mathrm{~m} . \mathrm{y}$.). The total span of time between the youngest cherts at Site 164 and at Site 165 is thus about 10 m.y. 
Because the youngest cherts are not of the same age everywhere, care must be exercised in interpreting seismic reflection profiler records. The cherts commonly produce good reflectors in the profiler records, although the Oligocene chert at Site 164 produces only weak and discontinuous reflections. Regional correlation of the strong acoustic reflectors associated with the cherty layers-Horizon " $\mathrm{A}$ "-is a purely geophysical correlation and may cut across biostratigraphic lines.

By focusing attention on the highest occurrence of chert, or on the prevalence of chert in the Middle Eocene (as compared to younger strata), it is easy to lose sight of the fact that chert is prevalent below as well as within the Middle Eocene. Pre-Middle Eocene-Cenozoic sediments are poorly represented at Leg 17 sites, but where they are present, they are cherty. At most sites on Leg 17, the Cretaceous sediments, whether calcareous or brown clay, are cherty. The exceptions are the volcanoclastic turbidites at Site 165, and the shallow-water limestone and volcanoclastic sediments at Site 171, on Horizon Guyot. In explaining the Middle Eocene cherts, the problem is not only to explain the presence of the chert, but also to explain its near absence in post-Eocene beds in the central Pacific.

The other anomalous feature of the early Cenozoic in the central Pacific is the dearth of sediments of pre-Middle Eocene age. At two sites, 164 and 165, a few scraps of Lower Eocene were identified, and at Site 167 (Magellan Rise), Paleocene and Danian beds are represented mainly by core-catcher samples from an interval less than 40 meters thick. At several sites $(164,166,171)$, Middle Eocene beds rest unconformably on Cretaceous strata, and at all other sites the average rate of accumulation during early Cenozoic times must be very small. (See rate of accumulation curves in Figure 1). In contrast, the accumulation rates for underlying Upper Cretaceous beds are commonly as high or higher than the post-Eocene rates. The upward increase in average accumulation rates is more difficult to define. Late Eocene rates appear normal; i.e., like Oligocene, but cherty Middle Eocene rocks are generally hard to sample. Middle Eocene times are probably most simply seen as a transition zone from very low rates below to faster rates above.

The explanation for these anomalous features of early Cenozoic stratigraphy is probably to be sought in very large-scale-perhaps even global-phenomena, rather than in local effects. The anomalies affect all sites, regardless of paleodepths or paleolatitudes, though these factors may modify results locally. Thus, the effects of plate motions (including subsidence) are probably secondary. More likely explanations lie in changes in the overall fertility or fertility patterns of the oceans, and in changes in solution levels-the CCD and lysocline-for calcium carbonate. An abundance of chert and moderate accumulation rates, as in the Middle Eocene, suggests an ocean fertile enough to produce lots of biogenous silica, but one in which a shallow CCD prevents much accumulation of carbonate, whereas the very low accumulation rates of Paleocene and Danian times, even in regions of equatorial paleolatitude and relatively shallow depth, suggest not only a shallow CCD, but perhaps low fertility as well. A model combining the changing effects is shown schematically in Figure 3.

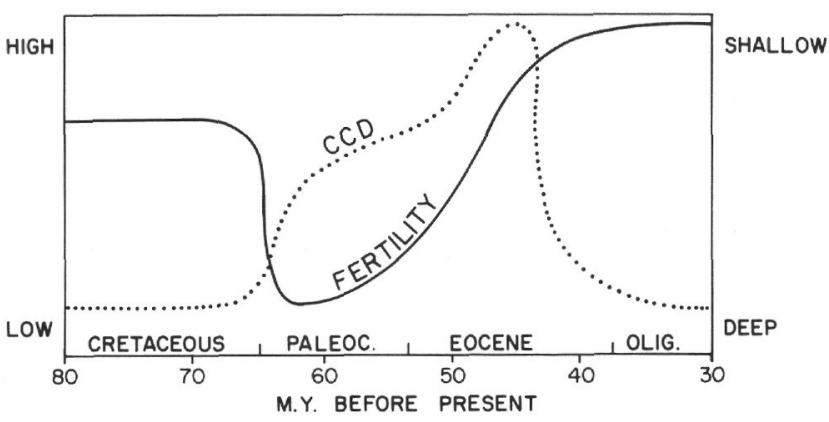

Figure 3. Schematic model of changes in fertility and calcium carbonate compensation depth (CCD). Times of deep $C C D$ and high fertility result in fast accumulation rates of biogenous $\mathrm{CaCO}_{3}$ (Cretaceous, Oligocene). High fertility and shallow $C C D$ result in biogenous silica undiluted with much $\mathrm{CaCO}_{3}$ (Middle Miocene). Low fertility and moderately shallow CCD result in low accumulation rates of both silica and $\mathrm{CaCO}_{3}$.

A dramatic drop in ocean fertility has been postulated by Bramlette (1965) to account for the great changes in fossil plankton at the Cretaceous-Tertiary boundary. $\mathrm{He}$ suggested decreased rates of supply of nutrients from the land as the underlying cause of the lower oceanic fertility. Other possible causes of lower fertility would include an increase in the stability of the density stratification of the ocean, resulting in a poorly stirred ocean, with only a small proportion of deep-water nutrients being recycled to the surface, or a fractionation of nutrients between different oceans or between shallow shelves and oceans (Berger, 1970). It is difficult to reconstruct the patterns of global deep-water circulation for the early Cenozoic because the geology of the potential connecting links between major ocean basins (e.g., the Scotia Sea) is still obscure. The closing of the Panama connection-at least in deep water-at the close of the Cretaceous may have isolated the Pacific and Atlantic deep waters from each other, and reestablishment of a link may have awaited the opening of the Southern Ocean between Antarctica and Australia, about 45 million years ago. The Pacific then, as now, was fringed by trenches and mountains, and far fewer nutrient-carrying large rivers emptied into the Pacific than into the Atlantic. Isolation of the Pacific might well leave it undernourished.

The sudden acceleration of accumulation rates of equatorial biogenous sediments during the Middle and Late Eocene, culminating in the very high rates of the Oligocene and Early Miocene, can be explained as the response to the opening of the Southern Ocean and the reestablishment of a global deep-water ciruclation scheme. As the opening widened, the flow of deep, cool, nutrient-rich "Antarctic" waters into the Pacific increased, as reflected in the declining isotopic temperature curves for Oligocene planktonic and benthonic foraminifera, reported in another chapter in this volume.

Causes of changes in the CCD are even less certain than for fertility because there are complex feedback loops between the two. If fertility (and shell-production and fallout rates) are very low, then the CCD can rise to shallow 
depths because it is an equilibrium depth, where rate of dissolution and rate of supply are matched. Such a situation may have prevailed during Paleocene and Early Eocene times. The middle Eocene requires another explanation, because the increases in fertility at that time should have resulted in increased rates of shell production and a depression in the CCD, whereas the opposite effect is proposed in the model to account for the abundance of silica and the dearth of carbonates. It is tempting to invoke basin-shelf fractionation of carbonates brought on by the well-known Middle Eocene transgression that affected so many parts of the world. Calcium carbonate fixed on the expanded shelves would be unavailable to the deep sea, and the compensation depth should rise.

\section{Cretaceous}

Beds of Cretaceous age were sampled at every site (treating 168 and 169 as a single site) on Leg 17, but core recovery rates were mainly low, owing to the presence of chert. Upper Cretaceous sediments are well-represented in several facies: calcareous, including both pelagic and shallow-water; brown clay; volcanogenic; and turbidites. Lower Cretaceous strata were sampled at Site 164 (Aptian or Barremian), Site 166 (Hauterivian [?] to Albian), Site 167 (Beriassian to Albian), Site 169 (Albian), and Site 170 (Albian). Pelagic limestones, brown clays, and volcanogenic sediments are represented.

Interpretation of Cretaceous sediments in the central Pacific in terms of solution levels is hazardous, because most sites probably have a complex history of subsidence and elevation. Sites 167 (Magellan Rise) and 171 (Horizon Guyot) were probably at all times during the Cretaceous shallower than the CCD. Site 171 began its subsidence from sea level, but at Site 167, neither the starting depth nor the trajectory are known. Assuming only isostatic subsidence, the CCD would have been deeper than about 3500 meters during all of Cretaceous times.

Site 164 is on "normal" oceanic crust about 110 million years old, and was probably above the CCD for the first few million years, but it was below the CCD by Cenomanian/ Turonian times ( 87 to $100 \mathrm{~m} . \mathrm{y}$.). The paleodepth at this time, assuming a normal subsidence path (Sclater et al., 1971), would be no more than about 4000 meters.

At Site 166, also on "normal" crust, the CCD was deeper than the site in Hauterivian times, though probably not much deeper, judging by the high clay content of the basal sediments. Within 15 m.y. (by Albian times) the site lay deeper than the CCD. The present water depth at Site 166 is shallower by about 700 meters than the "normal" depth for its age. If it has always had that difference, and if it followed the normal subsidence curve, the CCD would have been crossed at about 3200 meters, about 105 million years ago; if the 700 meter anomaly is due to more recent uplift, the calculated CCD would be at about 4000 meters.

Site 169 may be on "normal" crust, although the extraoridnary smoothness of acoustic basement and the nearness to the Marshall Islands make this assumption suspect. The site was above the CCD in Albian (100 to 104 m.y.), but was below it during Turonian (87 to 91 m.y.) times. On normal subsidence curves, the site passed across the CCD at a depth of about 3400 meters about 90 million years ago, but the $\mathrm{CCD}$ rose above the site again from 80 million years ago to the close of the Cretaceous. The possibility of post-Turonian uplift (resulting in a deeper calculated CCD) should be kept open.

The acoustic basement at Site 170 is thought to be an intrusive sill and may be much younger than the true oceanic crust. If we assume normal crust and normal subsidence, the following history is deduced: The site remained above the CCD as it subsided from about 2800 meters to 4300 meters from 104 to 80 million years ago. During early Campanian times, about 80 million years ago, it was deeper than the CCD, but only for a very short while. Then it was again above the CCD, where it stayed until about 70 million years ago.

These "back-tracked" depths are shown in Figure 4, plotted in a depth-latitude frame (see Berger, 1973, for details on the method). Making allowances for possible post-Cretaceous uplift or faster-than-normal subsidence of some of the sites, the general picture that emerges is a position of the CCD around 4000 meters in depth during the Middle and Late Cretaceous, with perhaps a deepening to around 4500 meters during the late Campanian and Maastrichtian. The bends in the curves have no significance in view of all the uncertainities in constructing the figure. Many more drill sites with continuous core recovery would be required before a reliable history of solution and levels can be written for the Cretaceous of the central Pacific.

Assuming that the CCD levels in Figure 4 are approximately correct, at least in suggesting a deepening of the compensation level in very late Cretaceous times, as contrasted to, say, Turonian times, it is interesting to compare this trend to the trend of isotopic temperatures measured on benthonic and planktonic foraminifera (Douglas and Savin, Chapter 00; Coplan and Schlanger, Chapter 00, this volume), and to the evidence for unconformities and slow average rates of accumulation in late Cenomanian to early Campanian times (95 to 78 m.y.).

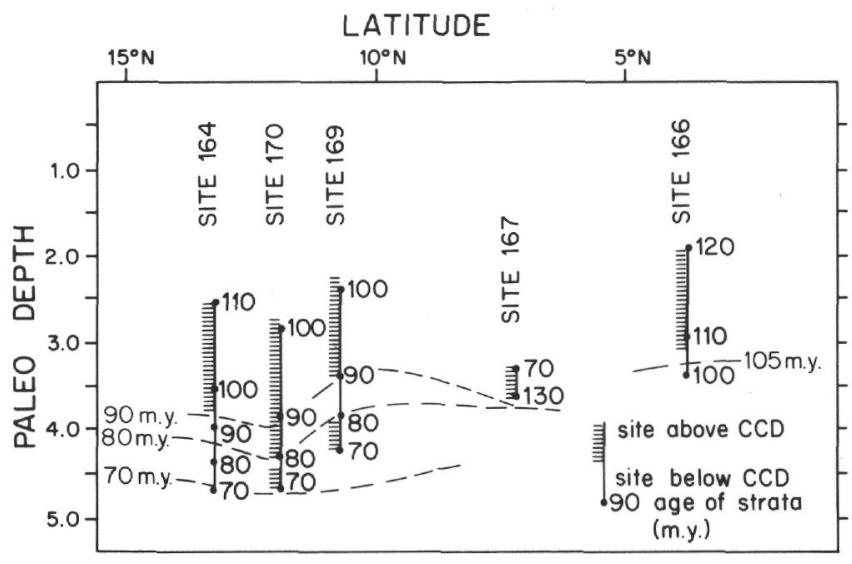

Figure 4. Plot of estimated paleodepths vs. latitude for Cretaceous sediments at Central Basin sites drilled on Leg 17. Presence or absence of $\mathrm{CaCO}_{3}$ gives position relative to calcium carbonate compensation depth (CCD). Deduced position of CCD at various times shown by dashed lines. See Berger (1973) for details of plotting paleodepths. 


\section{REFERENCES}

Berger, W. H., 1970. Biogenous deep-sea sediments: fractionation by deep-sea circulation: Geol. Soc. Am. Bull., v. 81, p. 1385-1402.

1973. Cenozic sedimentation in the eastern tropical Pacific: Geol. Soc. Am. Bull., v. 84, No. 6.

Bramlette, M. N., 1965. Massive extinctions in biota at the end of Mesozoic time: Science, v. 148, p. 1696-1699.

Chase, T. E., Menard, H. W., and Mammerickx, J., 1971. Topography of the North Pacific (Chart TR-14): La Jolla, Inst. of Marine Resources, Univ. Calif. at San Diego.

Hamilton, E. L., 1956. Sunken islands of the Mid-Pacific Mountains: Geol. Soc. Am. Mem., 64, p. 97.

Hayes, D. E. and Pitman, W. C., III, 1970. Magnetic lineations in the North Pacific: In Hayes, J. D. (Ed.), Geological investigations of the North Pacific, Geol. Soc. Am. Mem., v. 126, p. 291-314.

Larson, R. L. and Chase, C. G., 1972. Late Mesozoic evolution of the western Pacific Ocean: Geol. Soc. Am. Bull., v. 83, p. 3627-3644.
Larson, R. L., Smith, S. M., and Chase, C. G., 1972. Magnetic lineations of Early Cretaceous age in the western equatorial Pacific Ocean: Earth and Planet. Sci. Letters, v. 15, p. 315-319.

Lonsdale, P., Normark, W. R., and Newman, W. A., 1972. Sedimentation and erosion on Horizon Guyot: Geol. Soc. Am. Bull., v. 83, p. 289-316.

Menard, H. W. and Atwater, T., 1968. Changes in direction of sea floor spreading: Nature, v. 219, p. 463-467.

Sclater, J. G., Anderson, R. N., and Bell, M. L., 1971. The elevation of ridges and the evolution of the central eastern Pacific: J. Geophys. Res., v. 76, p. 7888-7915.

Winterer, E. L., 1973. Sedimentary facies and plate tectonics of the equatorial Pacific: Am. Assoc. Petrol. Geol. Bull., v. 57, p. 265-282.

Winterer, E. L., Riedel, W. R., et al., 1971a. Site 66: Initial reports of the Deep Sea Drilling Project, Volume 7. Washington (U.S. Government Printing Office), p. 725-819.

1971b. Site 65: Initial Reports of the Deep Sea Drilling Project, Volume 7. Washington (U. S. Government Printing Office), p. 607-723. 